\title{
EVALUATION OF DELAY CHARACTERISTICS AT SIGNALIZED INTERSECTIONS FOR IMPROVEMENT IN LEVEL OF SERVICE
}

\author{
Adepu Ramesh ${ }^{1}$, Kumar Molugaram ${ }^{2}$ \\ ${ }^{1}$ Department of Civil Engineering, VNR Vignana Jyothi Institute of Engineering and Technology, \\ Hyderabad, Telangana, India \\ ${ }^{2}$ Department of Civil Engineering, University College of Engineering Osmania University, Hyderabad, \\ Telangana, India
}

Received 24 March 2018; accepted 15 May 2018

\begin{abstract}
In our country traffic flow is heterogeneous and is governed by traffic characteristics as driver behavior, road geometry etc. Increase in traffic volume and limited road way width should be promptly addressed by traffic engineers who shall provide solutions which shall be more competent than traditional signalized designs. The recommendations suggested by the traffic engineer for improving signalized intersection shall be less expensive than providing interchanges. Metropolitan cities like Hyderabad are also experienced with delay and congestion due to ineffective traffic signal operation. Non -lane based traffic behavior, varying pavement width and driver characteristics are a few reasons for delay and congestion on our city roads. Improvement in the above context can be achieved through lane prioritization, alternative routes etc. This improvements will certainly reduce the impact on fuel consumption, improves safety and Level of Service at signalized intersection. In this context a study was carried at selected four major intersections (Bowenpally, Fathenagar, Balanagar and Alwyn) in Hyderabad city and was evaluated for existing traffic signal facilities. Parameters such as delay and queue length and Level of Service (LOS) were considered for evaluation. It is observed from simulation results that all the four intersections provide longer delay, larger queue length on major approaches of the intersections. These intersections were improved by providing alternative route for U-turn and left turn traffic movements which is achieved through channelization. Delays, average queue lengths were improved at all the four intersections. This has also resulted in achieving improved of level of services at the all signalized intersections.
\end{abstract}

Keywords: delay, average queue length, network performance, level of service.

\section{Introduction}

Hyderabad Metropolitan Development Authority (HMDA) is the sixth largest city in India, with a population of 7.1 million in the year 2014. The city is one of the fastest growing metropolitan cities with a decadal growth rate of $32 \%$.The urban agglomeration of Hyderabad spread over an area of $650 \mathrm{sq}$. $\mathrm{km}$ which comprises Hyderabad, and twelve other municipal entities surrounding it. Hyderabad is located along the banks of the Musi River. Regionally, Hyderabad lies on the convergence of national highways, state highways, rail routes and air routes, which link it's with other metropolitan centres and key centres of importance in the country.

\footnotetext{
${ }^{1}$ Corresponding author: ramesh_a@vnrvjiet.in
} 
The city is experiencing rigorous changes in its infrastructure which is due to rapid urbanization, service oriented activities and industrial development. The city also exhibits that vehicular growth is not in proportionate with the available road geometry. Most of the urban roads in HMDA area are static in behaviour during peak hours. This is leading to traffic congestion and in-turn to endless transportation gridlocks which has a direct impact on economy.

\subsection{Vehicular Growth and Composition}

The number of vehicles registering in the city is also nurturing at a rapid pace which is similar to that of population in our city. Over the last decade in Hyderabad two wheelers have increased by 56 percent, four wheelers 27 percent and three wheelers 50.4 percent. The modal share of private vehicle (cars, three wheelers and two wheelers) is about 61 percent. This is because in dearth of public transportation in terms of number of buses per commuter, frequency and its coverage at various internal parts of the city; as a reason of this private vehicle ownership has increased drastically.

\subsection{Traffic Problems in Hyderabad City}

Following are the characteristics of traffic problems in the city, specifically in high volume corridors.

a. Congestion levels have increased which has resulted in reducing average journey speeds to $18 \mathrm{KMPH}$ in central business developed areas of the city (CBD) (Source: City Development Plan, Greater Hyderabad Municipal Cooperation (GHMC)) b. Delay at signalized intersections, which is due to the absence of lane based traffic system. This is also increase threat to safety of road users.

c. Indiscipline parking by the vehicle owners at all CBD areas in the city.

d. There is an increase in vehicular volumes of para - transit vehicle facility. (three wheeler) This increase the maneuverability problem, indiscriminate stoppages so as to serve the passengers / commuters in the existing traffic situation.

e. Two wheeler mode shares had increased drastically.

f. Varying carriageway widths creating turbulence in traffic flow.

\subsection{Need for the Study}

The purpose of this study is to develop a process for automating traffic delay which shall improve the existing traffic situations. From the delay parameters Level of Service are computed and are compared with alternatives suggested for traffic movements at all study locations.

\subsection{Objectives of Present Study}

The objective of this paper is to study the improvement in traffic situations at selected signalized intersection which are served by motorized transportation.

a. To simulate and evaluate traffic parameters of selected study area using microscopic simulation technique.

b. To propose an alternative routes / priority based on selected study intersections for improving the existing traffic situations and LOS. 


\section{Literature Review}

Extensive studies were carried for improving the traffic situation in urban locations. One of the most prominent early works is (Webster, 1958) explained signal time setting characteristics for arriving analytical delay and queuing parameters. (Sadoun, 2003) explained that city traffic light control is a complex, challenging problem and makes difficult to perform analyses with traditional analytical techniques. The results showed an improvement in vehicular delay and minimizing the corresponding queue length at signalized intersections. (Cheng et al., 2005) explains the use of HCM (2000) for estimation of capacity and delay at signalized intersections. (Qi et al., 2007) determined the lengths of left-turn lanes at signalized intersections by considering the possibility of residual queues. (Hellinga and Abdy, 2008) has elaborated that traffic signal timing plans are typically developed on the basis of turning movement traffic and pedestrian volume. In India traffic behavior is heterogeneous characterized by diverse vehicles, lack of lane discipline and results in a very complex behavior (Mathew and Radhakrishnan, 2010). This provides difficulty for every vehicle to be moving in lane based. (Murat et al., 2014) explored the relationship between cyclic time, vehicle queue and vehicular delay importance at signalized intersection. (Yao and Michael Zhang, 2013), (Yao, 2013; Yao, 2014). (Chai and Wong, 2014) analysed the delay of shared lanes at signalized intersections under different proportions of through and right-turn movements and considering the blockage of either of movements. (Nyantakyi et al., 2014) explained signalized intersections are vital nodal points in a transportation network and their efficiency of operation greatly influences the entire network's performance. The study concluded that changes in phasing plan with geometric improvement would improve upon the intersection's level of service. (Farivar and Tian, 2016) explained the probabilistic delay model for signalized intersections with right-turn channelization lanes considering the possibility of blockage. Many traffic simulation models are used in various combinations to quantify the traffic signals characteristics. However, the findings of traffic simulation models are not widely adopted for improving urban intersection like Hyderabad city. In this connection an attempt is made for improving the traffic situation by providing alternative directions and lane priority at selected intersections of Hyderabad city using microscopic simulation techniques.

\section{Methodology}

The current study has been carried out in 5 stages as listed below:

- $\quad$ Stage 1: Collection of Literature;

- Stage 2: Traffic data collection through primary and secondary sources;

- Stage 3: Development of base model for all the study locations / intersections;

- Stage 4: Evaluation of existing and alternatives direction routes through simulation techniques;

- Stage 5: Results summarization and Conclusions.

Traffic micro-simulation software VISSIM $($ C 6 (PTV, 2014) was used to arrive the base situation of traffic. Following are parameters considered in development of base model and are discussed as follows. (i) Lane Behaviour: The lane changing behavior on urban roads for Indian conditions were used in simulation model; (ii) Traffic Heterogeneity: 
The data collected from the site was used in each intersection to obtain the traffic heterogeneity. The heterogeneous traffic was converted into homogeneous traffic stream with the corresponding Passenger Car Unit (PCU) equivalency factors (Chandra, 2008); (iii) Traffic Signal process: Cycle length, green split time, clearance, phasing was designed and used for evaluation; (iv) Traffic Characteristics: Traffic volumes, turning movements and vehicle compositions for each approach were collected in the field and was arrived for peak hour volume; (v) Vehicle Classification: Vehicles were classified as buses, passenger car, two wheelers three wheelers, HCV etc. The base model was developed considering Indian vehicular dimension and was implemented in VISSIM 6; (vi) Vehicular Speeds: The vehicular speeds were arrived as per the field study; Other Vehicular characteristics as maximum acceleration deceleration, power and vehicle weight, pedestrian interference with the traffic flow were not considered in the scope of the study.

The travel time delay was measured considering the average queue length in each approach of intersections. Average control delay which is arrived from (HCM, 2010) does not consider the delay due to acceleration to desired speed. Therefore, the delay arrived from microscopic simulation observations are slightly greater than field estimates of control delay (Tian et al., 2002). The calibration parameters were used at Bowenpally, Intersection which was validated on remaining intersections in the study (Fathenagar, Balanagar and Alwyn intersections). The root mean square error in delay was within the permissible limits and hence confirms for validation.

The developed model was later simulated for both with and without priority, alternative scenarios to appreciate the efficacy in prioritization techniques for the existing traffic situation as shown in Fig. 1. The alternatives demonstrated that the existing roads when allowed for priority traffic routes provides improvement in delay and level of service characteristics than approaches with existing road geometry, on-street parking and improper bus bays.

\section{Data Collection}

\subsection{Study Area}

The study area is located on National Highway ( $\mathrm{NH}-65)$ corridor and is passing through Bowenpally, Fathenagar, Balanagar and Alwyn intersection as shown in Fig. 1. Bowenpally is four legged intersection with a provision of bus stop situated at $100 \mathrm{~m}$ from the intersection. Fathenagar is three legged intersection having on street parking facility on the major approach for three wheeled vehicles. Balanagar is four legged intersection with bus stops situated at $100 \mathrm{~m}$ on two approaches and with onstreet parking facility for three wheeled vehicles. Alwyn intersection is three-legged intersection without on-street parking facilities. All the four intersections are referred as critical due to highest level of interactions of motorized traffic. In this connection the study has suggested for traffic route alternatives, lane priority for straight and ' $U$ ' turn flow as shown in Fig. 1 


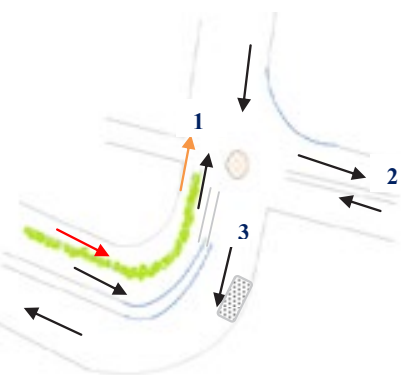

(a) Bowenpally Intersection
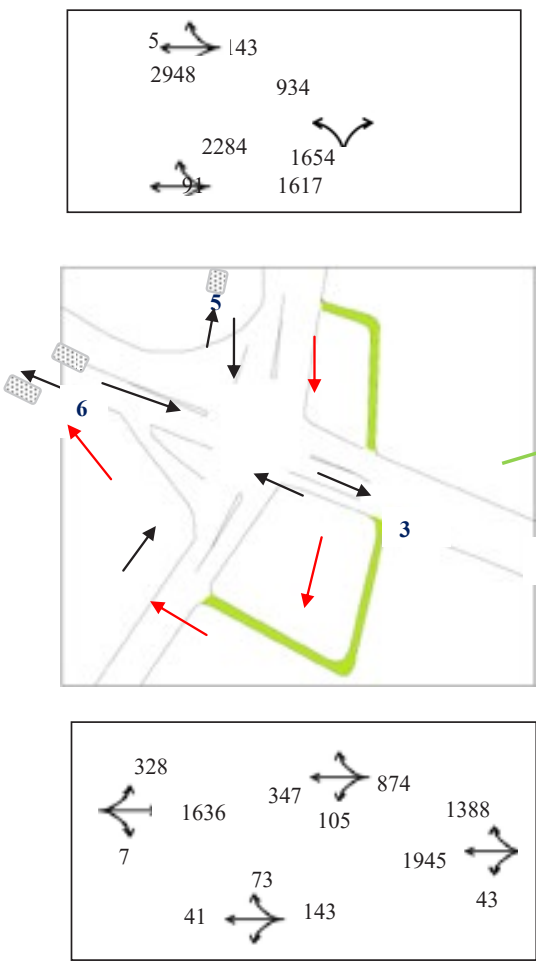

(c) Balanagar Intersection
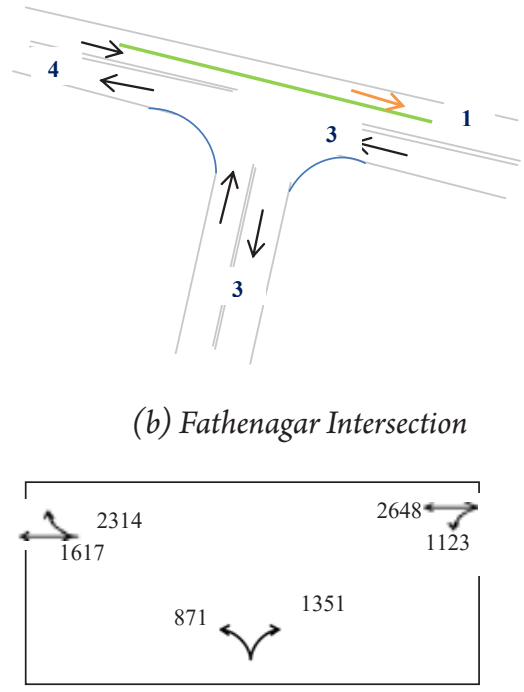

(b) Fathenagar Intersection
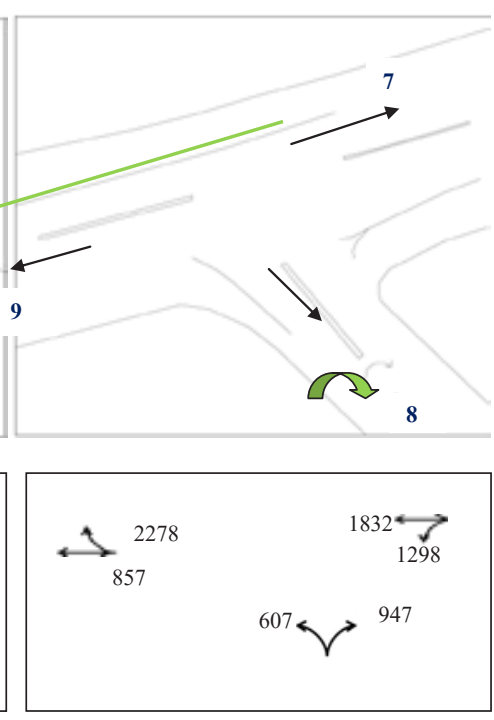

(d) Alwyn Intersection

Represents alternative directions, priority lanes for straight and ' $U$ ' turn flow at study locations Bus Stop location

\section{Fig. 1.}

Geometrical View with Volume and Alternative Route Directions at Study Locations 1: Towards Bowenpally; 2: Towards Secunderbad; 3: Towards Fathenagar ; 4 : Towards Balanagar; 5: Towards Jeedimetla; 6: Towards Y Junction; 7:Towards:Miyapur; 8: Towards Kondapur; 9: Towards Lingampally 
Traffic data was collected at all four intersections during morning and evening periods of week day traffic through video recording technique and is shown in Fig. 1.

This data is used as input for development of base model and for evaluation of existing situation using microscopic simulation technique. Performance of improvement was measured by considering delay as parameter by providing alternatives route directions and lane priority. Optimum cycle time, phases, minimum green time, clearance times were designed using IRC and was simulated using VISSIM 6.

\section{Results and Discussion}

Peak hour volume at all the four intersections was considered for signal design. Mode share observations and peak hour volume is shown in Figs. 2, 3, 4 and 5.
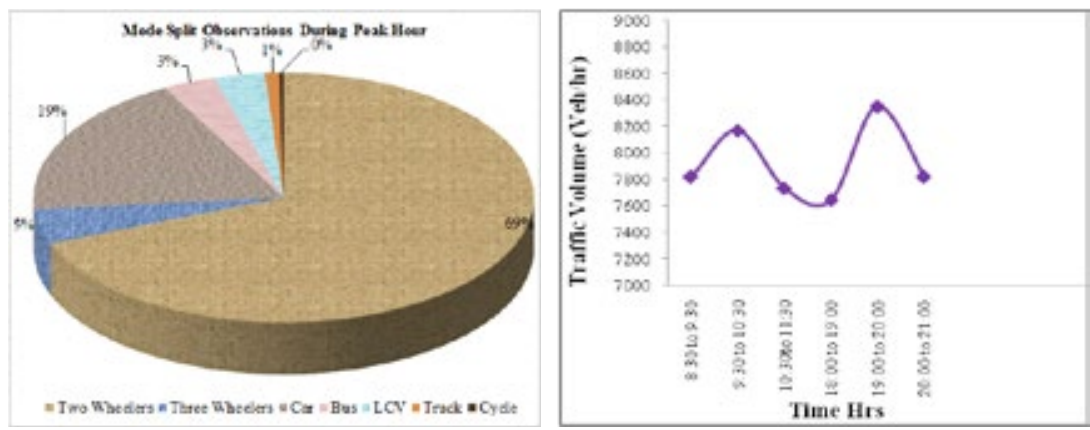

Fig. 2.

Mode Split and Peak Hour Traffic Flow Variation at Bowenpally Intersection
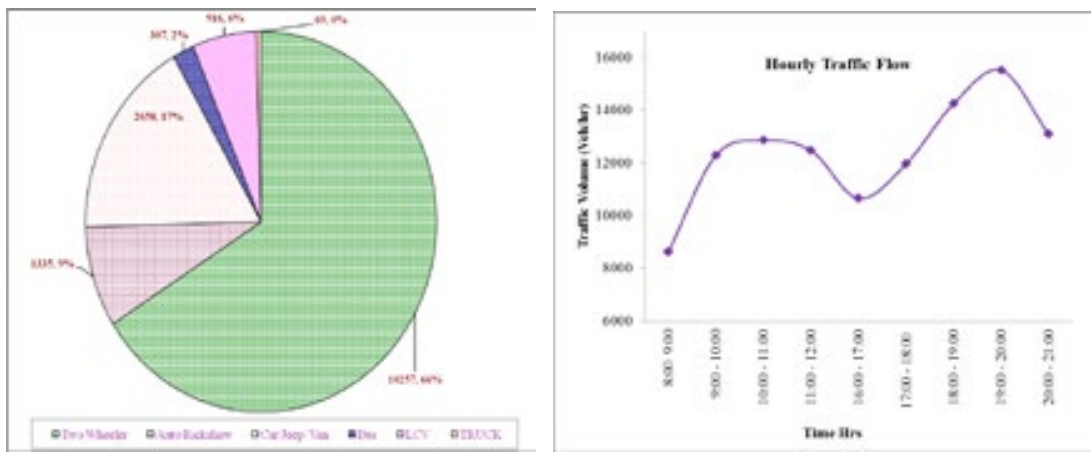

Fig. 3.

Mode Split and Peak Hour Traffic Flow Variation Fathenagar Intersection 

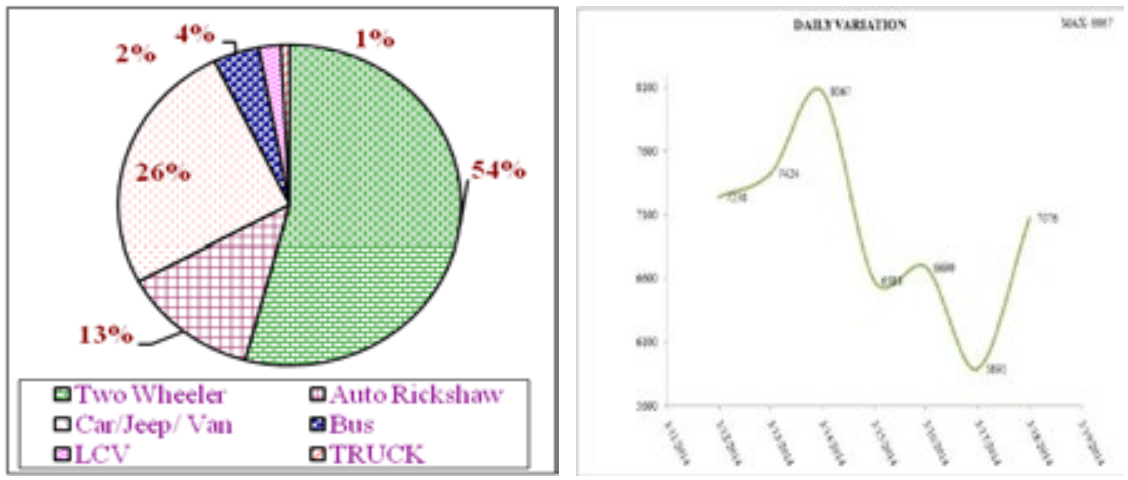

Fig. 4.

Mode Split and Peak Hour Traffic Flow Variation Balanagar Intersection
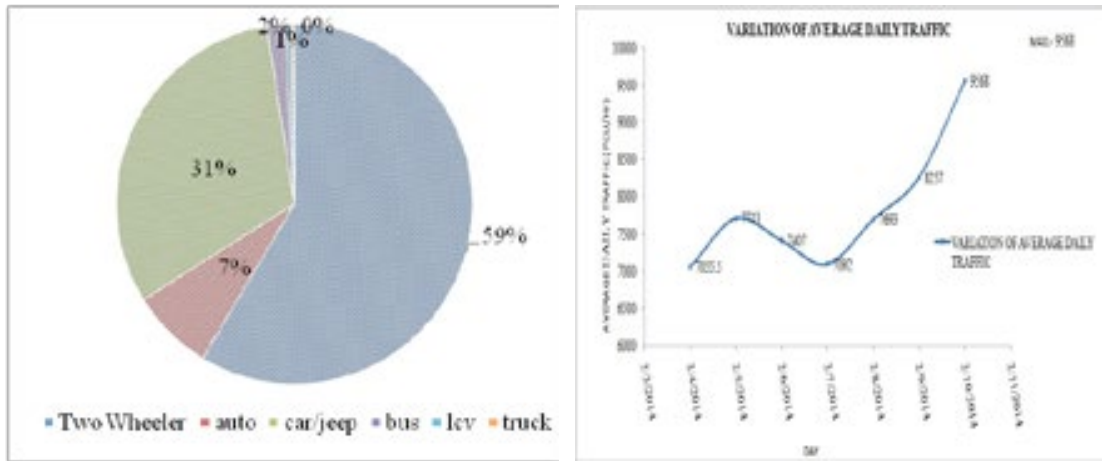

Fig. 5.

Mode Split and Peak Hour Traffic Flow Variation Alwyn Intersection

The composition of two wheelers is close to $58 \%$ at all the four intersections, next share composite to passenger car of $30 \%$ and remaining to three wheelers, LCV, buses and Truck.

\subsection{Improvements at Study Locations for Alternatives}

Bowenpally Intersection

Traffic simulation is carried for Bowenpally Intersection with and without providing priority. It is observed that the delays are reduced from $165.7 \mathrm{sec}$ to $37.9 \mathrm{sec}$ and is shown in Table 1 . 


\section{Table 1}

Simulation Results without and with Prioritization(Left Lane) At Bowenpally Intersection

\begin{tabular}{|c|c|c|c|c|c|c|c|c|}
\hline \multirow{2}{*}{$\begin{array}{c}\text { From } \\
\text { link }\end{array}$} & \multirow{2}{*}{$\begin{array}{l}\text { Vehicles } \\
\text { Originating } \\
\text { from }\end{array}$} & \multirow[b]{2}{*}{ To link } & \multirow{2}{*}{$\begin{array}{c}\text { Vehicles } \\
\text { Designating } \\
\text { to }\end{array}$} & \multirow{2}{*}{$\begin{array}{l}\text { Direction } \\
\text { of Traffic }\end{array}$} & \multicolumn{2}{|c|}{ Without Improvement } & \multicolumn{2}{|c|}{ With Improvement } \\
\hline & & & & & $\begin{array}{l}\text { Delay } \\
\text { (Sec) }\end{array}$ & $\begin{array}{c}\text { Queue length } \\
(\mathrm{m})\end{array}$ & $\begin{array}{l}\text { Delay } \\
(\mathrm{Sec})\end{array}$ & $\begin{array}{c}\text { Queue } \\
\text { length }(\mathrm{m})\end{array}$ \\
\hline 1 & Fathenagar & 4 & Bowenpally & Straight & 58.4 & 42.0 & 58.4 & 42 \\
\hline 2 & Secunderbad & 3 & Bowenpally & Right Turn & 85.6 & 30.7 & 25.4 & 10.0 \\
\hline 5 & Fathenagar & 6 & Secunderbad & Right Turn & 129.9 & 109.3 & 129.9 & 109.3 \\
\hline 7 & Bowenpally & 8 & Fathenagar & Straight & 35.0 & 13.7 & 35.0 & 13.7 \\
\hline 9 & Secunderbad & 10 & Fathenagar & Left Turn & 165.7 & 46.1 & 37.9 & 12.0 \\
\hline 11 & Bowenpally & 11 & Secunderbad & Left Turn & 27.7 & 20.0 & 27.7 & 20.0 \\
\hline
\end{tabular}

It is observed from the above Table that link 9 - 10 (i.e.) Secunderbad to Fathenagar has the delay of $65.7 \mathrm{~s}$ due to conflict area between motorists from Secunderbad to Fathenagar and Fathenagar to Secunderabad. This is improved through prioritization of left side traffic movement of Fathenagar to Secunderabad approach.

\section{Fathenagar Intersection}

Fathenagar Intersection a three legged ' $\mathrm{T}$ ' intersection. Major approach is running through Bowenpally and Balanagar. Minor approach connects to Fathenagar. Free left lane is suggested through prioritization and simulated for with and without improvements as in shown Table 2.

It is observed from the Table 2 that the link 8 - 9 (i.e.) Fathenagar to Balanagar has a vehicular delay of 202.5 s. This is mainly due reduction of left lane at Fathenagar approach which is occupied by three wheelers parking and is resulting in enormous conflicts between motorists link 9-8. Improvement of this is a result of left traffic lane prioritization from Fathenagar to Balanagar and Balanagar to Bowenpally with improvement in delay as $202.5 \mathrm{~s}$ to $30 \mathrm{~s}$ and 124 to $12.8 \mathrm{~s}$.

\section{Table 2}

Simulation Results without and with Prioritization at Fathenagar Intersection

\begin{tabular}{|c|c|c|c|c|c|c|c|c|}
\hline \multirow{2}{*}{$\begin{array}{l}\text { From } \\
\text { link }\end{array}$} & \multirow{2}{*}{$\begin{array}{c}\text { Vehicles } \\
\text { Originating } \\
\text { from }\end{array}$} & \multirow[b]{2}{*}{ To link } & \multirow{2}{*}{$\begin{array}{c}\text { Vehicles } \\
\text { Designating } \\
\text { to }\end{array}$} & \multirow{2}{*}{$\begin{array}{l}\text { Direction } \\
\text { of Traffic }\end{array}$} & \multicolumn{2}{|c|}{ Without Improvement } & \multicolumn{2}{|c|}{ With Improvement } \\
\hline & & & & & $\begin{array}{l}\text { Delay } \\
(\mathrm{Sec})\end{array}$ & $\begin{array}{l}\text { Queue length } \\
(\mathrm{m})\end{array}$ & $\begin{array}{l}\text { Delay } \\
(\mathrm{Sec})\end{array}$ & $\begin{array}{c}\text { Queue } \\
\text { length }(\mathrm{m})\end{array}$ \\
\hline 1 & Fathenagar & 12 & Bowenpally & Right turn & 52.5 & 54.9 & 28.2 & 54.9 \\
\hline 2 & Balanagar & 3 & Bowenpally & Straight & 186.5 & 87.8 & 0.0 & 0.0 \\
\hline 4 & Balanagar & 5 & Fathenagar & Right turn & 118.2 & 79.0 & 58.7 & 79.0 \\
\hline 6 & Bowenpally & 7 & Fathenagar & Left turn & 55.0 & 54.3 & 67.2 & 87.3 \\
\hline 8 & Fathenagar & 9 & Balanagar & Left turn & 202.5 & 90.3 & 30.0 & 23.0 \\
\hline 10 & Bowenpally & 11 & Balanagar & Straight & 124.0 & 81.3 & 12.8 & 35.0 \\
\hline
\end{tabular}

\section{Balanagar Intersection}

Balanagar Intersection is a four legged intersection. Major approach runs from Kukatpally to Fathenagar and Minor approach runs to a major approach Moosapet to Jeedimetla. Simulation is carried with and without alternative directions at the intersection. Alternative direction is provided for the traffic coming from Fathenagar to Balanagar. Results are tabulated in the Table 3. 
Table 3

Simulation Results without Left Lane Alternative Route at Balanagar Intersection

\begin{tabular}{|c|c|c|c|c|c|c|c|c|}
\hline \multirow{2}{*}{$\begin{array}{l}\text { From } \\
\text { Link }\end{array}$} & \multirow{2}{*}{$\begin{array}{c}\text { Vehicles } \\
\text { Originating } \\
\text { from }\end{array}$} & \multirow{2}{*}{$\begin{array}{c}\text { To } \\
\text { Link }\end{array}$} & \multirow{2}{*}{$\begin{array}{c}\text { Vehicles } \\
\text { Designating } \\
\text { to }\end{array}$} & \multirow{2}{*}{$\begin{array}{l}\text { Direction } \\
\text { of Traffic }\end{array}$} & \multicolumn{2}{|c|}{ Without Improvement } & \multicolumn{2}{|c|}{ With Improvement } \\
\hline & & & & & $\begin{array}{l}\text { Delay } \\
\text { (Sec) }\end{array}$ & $\begin{array}{c}\text { Queue length } \\
(\mathrm{m})\end{array}$ & $\begin{array}{l}\text { Delay } \\
(\mathrm{Sec})\end{array}$ & $\begin{array}{c}\text { Queue } \\
\text { length }(\mathrm{m})\end{array}$ \\
\hline 1 & Fathenagar & 1 & Kukatpally & Straight & 120.4 & 93.9 & 75.5 & 83.2 \\
\hline 1 & Fathenagar & 5 & Jeedimetla & Right Turn & 140.6 & 93.9 & 86.7 & 83.2 \\
\hline 1 & Fathenagar & 7 & Moosapet & Free Left & 123.8 & 65.5 & 10.0 & 57.9 \\
\hline 2 & Kukatpally & 1 & Y Junction & U Turn & 110.7 & 40.3 & 40.1 & 40.6 \\
\hline 2 & Kukatpally & 2 & Fathenagar & Straight & 52.7 & 40.3 & 9.0 & 40.6 \\
\hline 2 & Kukatpally & 7 & Moosapet & Right Turn & 20.9 & 40.3 & 0.0 & 0.0 \\
\hline 4 & Jeedimetla & 1 & Y Junction & Right Turn & 128.8 & 65.3 & 0.0 & 13.5 \\
\hline 4 & Jeedimetla & 2 & Fathenagar & Free Left & 67.1 & 23.8 & 26.2 & 35.6 \\
\hline 4 & Jeedimetla & 7 & Moosapet & Straight & 106.6 & 57.9 & 3.7 & 0.0 \\
\hline 6 & Moosapet & 1 & Kukatpally & Free Left & 4.1 & 10.1 & 0.0 & 0.0 \\
\hline 6 & Moosapet & 2 & Fathenagar & Right Turn & 2812.2 & 10.1 & 0.1 & 0.0 \\
\hline
\end{tabular}

From the simulation results it is observed that by providing alternative left direction route from Jeedimetla to Balanagar and Balanagar to Y Junction delays were reduced. The Average queue lengths are also reduced considerably.

\section{Alwyn Intersection}

Traffic simulation is carried at Alwyn intersection with and without providing U-turn priority. The simulation results for with and without priority are tabulated in Table 4.

Table 4

Simulation Results without U-Turn Priority at Alwyn Junction

\begin{tabular}{|c|c|c|c|c|c|c|c|c|}
\hline \multirow{2}{*}{$\begin{array}{l}\text { From } \\
\text { Link }\end{array}$} & \multirow{2}{*}{$\begin{array}{c}\text { Vehicles } \\
\text { Originating } \\
\text { from }\end{array}$} & \multirow{2}{*}{$\begin{array}{c}\text { To } \\
\text { Link }\end{array}$} & \multirow{2}{*}{$\begin{array}{c}\text { Vehicles } \\
\text { Designating } \\
\text { to }\end{array}$} & \multirow{2}{*}{$\begin{array}{l}\text { Direction } \\
\text { of Traffic }\end{array}$} & $\begin{array}{c}\text { Without } \\
\text { Improvement }\end{array}$ & $\begin{array}{c}\text { With } \\
\text { Improvement }\end{array}$ & $\begin{array}{c}\text { Without } \\
\text { Improvement }\end{array}$ & $\begin{array}{c}\text { With } \\
\text { Improvement }\end{array}$ \\
\hline & & & & & $\begin{array}{c}\text { Delay } \\
(\text { Sec })\end{array}$ & $\begin{array}{c}\text { Queue } \\
\text { length }(\mathrm{m})\end{array}$ & $\begin{array}{c}\text { Delay } \\
\text { (Sec) }\end{array}$ & $\begin{array}{c}\text { Queue } \\
\text { length }(\mathbf{m})\end{array}$ \\
\hline 1 & Lingampally & 1 & Miyapur & Free Left & 26.2 & 34 & 20.9 & 19 \\
\hline 1 & Lingampally & 2 & Lingampally & U Turn & 156.3 & 71 & 57.4 & 21 \\
\hline 1 & Lingampally & 4 & Kondapur & Right Turn & 68.4 & 36.3 & 53.2 & 40.8 \\
\hline 2 & Myiapur & 1 & Miyapur & U Turn & 74.9 & 50.9 & 68.7 & 44.3 \\
\hline 2 & Myiapur & 2 & Lingampally & Straight & 35 & 50.9 & 35 & 44.3 \\
\hline 3 & Myiapur & 4 & Kondapur & Left Turn & 32.6 & 0.0 & 31 & 0.0 \\
\hline 5 & Kondapur & 1 & Miyapur & Right Turn & 84.1 & 35.1 & 33.9 & 21.9 \\
\hline 6 & Kondapur & 7 & Lingampally & Left Turn & 11.2 & 0.0 & 12.0 & 0.0 \\
\hline 5 & Kondapur & 4 & Kondapur & U Turn & 1.0 & 0.0 & 1.0 & 0.0 \\
\hline
\end{tabular}

From the simulation results it is observed that delay is reduced from $156.3 \mathrm{sec}$ to $57.4 \mathrm{sec}$ for Lingampally to Lingampally approach.
The Average queue length is also reduced considerably. The variation in delay at all intersections (approach legs) is shown in Fig. 6. 


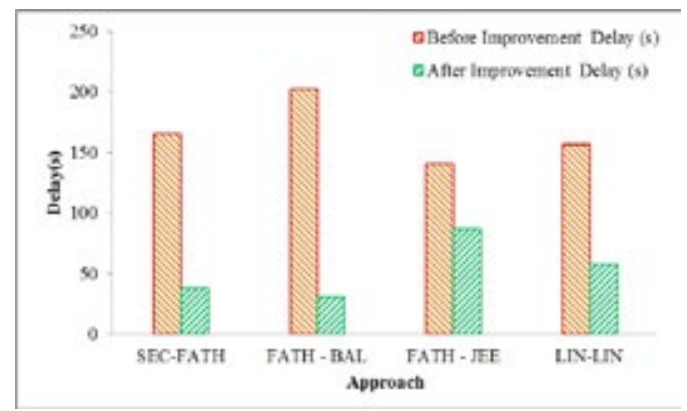

Fig. 6.

Variation in Delay Improvements at All Approaches of Intersections

\subsection{Effect in Level of Service for Improvements}

Delay parameters are used to estimate Level of Service (LOS). The LOS with and with prioritizations at all study locations is shown in Table 5. Further improvement in LOS was not possible because of the existing road geometry, land use pattern of commercial and industrial establishment.

Table 5

Level of Service at the All Four Intersections without and with Improvements

\begin{tabular}{|l|c|c|c|c|}
\hline \multirow{2}{*}{$\begin{array}{c}\text { Name of the } \\
\text { Intersection }\end{array}$} & $\begin{array}{c}\text { Without } \\
\text { Improvement }\end{array}$ & $\begin{array}{c}\text { With } \\
\text { Improvement }\end{array}$ & $\begin{array}{c}\text { Before } \\
\text { Improvement }\end{array}$ & $\begin{array}{c}\text { After } \\
\text { Improvement }\end{array}$ \\
\cline { 2 - 5 } & $\begin{array}{c}\text { Aggregate delay } \\
\text { (Sec's) }\end{array}$ & $\begin{array}{c}\text { Aggregate delay } \\
\text { (Sec's) }\end{array}$ & LOS & LOS \\
\hline Bowenpally & 83.76 & 52.1 & $\mathrm{~F}$ & $\mathrm{D}$ \\
\hline Fathenagar & 123.11 & 32.8 & $\mathrm{~F}$ & $\mathrm{C}$ \\
\hline Balanagar & 74.623 & 40.1 & $\mathrm{E}$ & $\mathrm{D}$ \\
\hline Alwyn & 54.11 & 39.1 & $\mathrm{D}$ & $\mathrm{C}$ \\
\hline
\end{tabular}

(Source for LOS calculations is per HCM, 2000)

It is inferred that Level of Service for all the intersections has improved. This is achieved because of providing alternative routes, lane priority for left turn's and straight flow movements at study intersections.

\section{Summary and Conclusions}

The study reveals that alternatives is an instrumental tool in reducing vehicular delay, queue length and level of service at urban intersections having heterogeneity road traffic conditions. The study also exhibits that delays and queue lengths are more due to the closely location of bus stops and on street parking for three wheeled vehicles, thus reducing the effective width of road after the intersections. It is also noticed form the volume data that two - wheelers constitute for highest mode share at all the four intersections. This evident that large portion of commuter's uses personalized mode share than public transport facility. Delay and queue lengths are reduced with the provision of alternative directional route for 2 -wheelers, ' $U$ ' turn priority ahead of intersection, through lane prioritization and regulation in left turn traffic movements at the study intersections. The Level of service has a significant improvement 
at all study intersections within the available road geometry.

\section{References}

Chai, C.; Wong, Y.D. 2014. Traffic performance of shared lanes at signalized intersections based on cellular automata modelling, Journal of Advanced Transportation 48(8): 1051-1065.

Chandra, S. 2008. Passenger car units for Indian roads, Journal of Indian Roads Congress 69(2).

Cheng, D.; Tian, Z.Z.; Messer, C.J. 2005. Development of an improved cycle length model over the highway capacity manual 2000 quick estimation method, Journal of Transportation Engineering 131(12): 890-897.

Farivar, S.; Tian, Z.Z. 2016. Modeling delay at signalized intersections with channelized right-turn lanes considering the impact of blockage, Journal of Advanced Transportation 50(8): 1666-1682.

HCM. 2000. Highway Capacity Manual. Transportation Research Board. National Research Council. Washington D.C.

HCM. 2010. Highway Capacity Manual 2010. Transportation Research Board. National Research Council. Washington D.C.

Hellinga, B.; Abdy, Z. 2008. Signalized intersection analysis and design: implications of day-to-day variability in peak-hour volumes on delay, Journal of Transportation Engineering 134(7): 307-318.

Mathew, T.V.; Radhakrishnan, P. 2010. Calibration of microsimulation models for nonlane-based heterogeneous traffic at signalized intersections, Journal of Urban Planning and Development 136(1): 59-66.

Murat, Y.S.; Kutluhan, S.; Cakici, Z. 2014. Investigation of Cyclic Vehicle Queue and Delay Relationship for Isolated Signalized Intersections, Procedia-Social and Behavioral Sciences 111: 252-261.
Nyantakyi, E.K.; Owusu, P.A.; Borkloe, J.K. 2014. Methods for the Assessment of Performance Indication Measures at Amakom Intersection and their Application in Micro Simulation Modeling, International Journal for Traffic and Transport Engineering 4(1): 35-51.

PTV. 2014. VISSIM(C 6 User Manual. PTV Planung Transport Verkehr. Karlsruhe. Germany.

Qi, Y.; Yu, L.; Azimi, M.; Guo, L. 2007. Determination of storage lengths of left-turn lanes at signalized intersections, Transportation Research Record: Journal of the Transportation Research Board 2023: 102-111.

Sadoun, B. 2003. An efficient simulation methodology for the design of traffic lights at intersections in urban areas, Simulation 79(4): 243-251.

Tian, Z.; Urbanik, T.; Engelbrecht, R.; Balke, K. 2002. Variations in capacity and delay estimates from microscopic traffic simulation models, Transportation Research Record: Journal of the Transportation Research Board 1802:23-31.

Webster, F.V.1958. Traffic Signal Settings. Department of Scientific and Industrial Research, Road Research Technical Paper No. 39, Her Majesty's Stationary Office. London. England.

Yao, R. 2013. Sensitivity analysis of optimization models for isolated intersections with short left-turn lanes on approaches, Journal of Advanced Transportation 47(1): 28-42.

Yao, R. 2016. Settings of short left-turn lane and signal phase sequence for isolated signalized intersections, Transport 31(4): 416-426.

Yao, R.; Michael Zhang, H. 2013. Optimal allocation of lane space and green splits of isolated signalized intersections with short left-turn lanes, Journal of Transportation Engineering 139(7): 667-677. 